\title{
Policías y criminales en el semidocumental argentino
}

\section{Pablo Lanza \\ Universidad de Buenos Aires, Argentina \\ pablohernanlanza@hotmail.com}

Recibido: 14/8/2020. Aceptado: 30/5/2021.

\begin{abstract}
Resumen
Un género de breve productividad de la industria cinematográfica argentina fue el policial semidocumental realizado durante los años del primer gobierno peronista. En él, se narraban historias que ensalzaban el accionar de la policía apelando a casos verídicos, la filmación en locaciones reales y el uso de la voz over. En este artículo nos proponemos examinar las formas en las que este subgénero se desarrolló en la Argentina y analizar el sistema de personajes masculinos, el cual puede dividirse en dos conjuntos: delincuentes y oficiales de la ley.
\end{abstract}

Palabras clave: semidocumental; masculinidad; ley; crimen, cine argentino.

\section{Policemen and criminals in the Argentine semidocumentary film}

\begin{abstract}
A genre of short productivity in the argentine film industry was the semidocumentary made during the years of the first peronist government. In it, stories were told that extolled the actions of the police by appealing to true cases, filming in real locations and using voice over. In this article we propose to examine the ways in which this subgenre developed and to analyze the male character system, which can be divided into two groups: criminals and law enforcement officers.
\end{abstract}

Keywords: semidocumentary; masculinity; law; crime; argentine cinema.

En este artículo nos proponemos trabajar sobre un conjunto de películas policiales argentinas realizadas en la década del cincuenta que se inscriben dentro del subgénero semidocumental con el objetivo de analizar las representaciones de sus personajes masculinos. Los años del ciclo semidocumental argentino coinciden con la llamada 
época de oro del policial, que va de 1947 a 1952 (Tassara, 1992), y con el primer gobierno peronista (1946-1952). Según Clara Kriger, en los policiales del periodo "confluyen, por un lado, una fuerte propaganda de las instituciones y, por otro, un cambio en la puesta en escena del delito, que comienza a salir de los interiores construidos en estudios cinematográficos para desarrollarse en las calles" (2009: 140).

Frente a la fuerte presencia femenina en el film noir, el semidocumental se caracteriza por la relativa ausencia de mujeres y los personajes masculinos pueden dividirse en dos grandes bandos: delincuentes y agentes de la ley. En este sentido, el subgénero continúa la noción de "melodrama para hombres" con el que se solía describir al film noir durante sus años de producción y, siguiendo dicha matriz cultural, trabaja a partir de un sistema de personajes que bien puede describirse como maniqueo: villanos y héroes, sin posiciones intermedias.

El subgénero semidocumental resulta idóneo para abordar la temática de género e identidad, en tanto se lo debe considerar como un ejemplo de cine de propaganda de las fuerzas de la ley. Como propone R.W: Connell, el género representa "un concepto que depende del momento histórico y se carga de sentido políticamente" (2003: 15). En este sentido, la representación de la masculinidad en estos films, a pesar de plantearse como realista, permite arrojar luz sobre los ideales de los ciudadanos de la época.

Para lograr nuestros objetivos, en primer lugar, definiremos qué se entendía por semidocumental en el período, a partir del análisis del modelo estadounidense que sirvió de inspiración, para luego examinar cómo fue adaptado en algunos de los ejemplos más renombrados de la filmografía argentina; en segundo término, examinaremos la concepción de los personajes masculinos propuesta en el corpus de trabajo a partir de la división entre policías y criminales.

\section{La adaptación de un estilo transnacional al cine argentino}

El estilo semidocumental surge en el cine estadounidense a mediados de la década del cuarenta con el film La casa de la calle 92 (House on 92nd Street, 1945), película que sienta las bases del estilo: "temas tomados de hechos reales, rodajes en los lugares donde se produjeron los acontecimientos, tono documental" (Coursodon, 1996: 287). El principal artífice del film fue el productor Louis de Rochemont, reconocido por su trabajo en el noticiero La marcha del tiempo (The March of Time, 1931-1945), del cual los semidocumentales toman varias características, especialmente en cuanto a la utilización del relato en voz over. Junto al realizador Henry Hathaway, continuarían trabajando dentro del estilo durante los siguientes años de forma conjunta en 13 Rue Madeleine (1946) y por separado: Crimen sin castigo (Boomerang, 1947, Elia Kazan), de Rochemont, y con El beso de la muerte (The Kiss of Death, 1947) y Yo creo en ti (Call Northside 777, 1948), de Hathaway.

Antes de adentrarnos en la producción argentina, mencionaremos brevemente las condiciones y características del estilo tal como se lo concibió dentro de la industria estadounidense, aspecto ineludible para comprender de qué manera fue adaptado para las pantallas argentinas. En primer lugar, resulta necesario señalar que el período en el que se realiza este ciclo coincide con el desarrollo del film noir, por lo que muchos estudios de este estilo suelen incluirlo en sus abordajes, ya sea para contraponerlos o buscar similitudes. El trabajo pionero sobre cine negro de los franceses Raymond Borde y Etienne Chaumeton incluye a estos films dentro de su recorte, pero inician su volumen señalando una serie de diferencias entre lo que denominan "serie negra" y los "documentales policiales". Los autores describen a estos últimos con las siguientes palabras: 
cintas que tienen por característica describir una investigación criminal siguiendo uno por uno los documentos de una carpeta policial. Por otra parte, un cartel o un comentario advierte al público desde el comienzo de la película que se trata de una historia verdadera, acaecida en tal época, Nueva York o donde quiera que sea (1958: 14).

Estéticamente, ambas modalidades parecen compartir algunos rasgos, tales como el uso de la narración con voces over, el rodaje en exteriores, "escenas harto brutales, y exuberantes desbordes en las persecuciones finales" (1958: 14). La principal diferencia que los autores señalan tiene que ver con una cuestión de perspectiva narrativa:

En el documental, la muerte está considerada desde afuera, desde el punto de vista de la policía oficial; en la película negra desde adentro, desde el punto de vista de los criminales [...] La segunda diferencia es de orden moral y acaso más esencial aún. Es tradición del documental policial presentar a los investigadores como hombres íntegros, incorruptibles y valientes (1958: 14-15).

Tomaremos a modo de ilustración el film La casa de la calle 92, que, como dijimos, no solo es el puntapié inicial del ciclo, sino que además sienta sus bases. El film narraba los esfuerzos por parte de los agentes del FBI por desenmascarar a un conjunto de espías nazis que trabajaron de forma encubierta en los Estados Unidos durante los años de la guerra. Un primer aspecto para remarcar es precisamente su carácter híbrido, a mitad de camino entre un relato policial y un documental sobre las técnicas de investigación, que se mantiene a lo largo de toda la película, característica que no será habitual en los ejemplos que le siguieron. Durante las escenas ficcionales se trabaja con una marcada puesta en escena que emplea iluminación con claroscuros similar a la estética expresionista. Por el contrario, las escenas documentales hacen gala de dos procedimientos: el uso de material de archivo y el relato en over de un narrador extradiegético. Sobre el primero de estos elementos, Canham indica que

El F.B.I, no solo proveyó material para las historias, sino que en el caso de La casa en la calle 92 también suministró metraje verdadero de agentes de la quinta columna trabajando -material que había sido filmado en secreto por sus propios agentes y que había sido información secreta durante la guerra- (1973: 160).

El material de archivo fílmico puede diferenciarse claramente debido a su textura, el fuerte granulado del $16 \mathrm{~mm}$. y la ausencia de sonido sincrónico. Esto nos conduce al segundo de los elementos, la utilización de la voz over, que se relaciona con los noticieros fílmicos producidos durante la guerra, dentro de los cuales se encuentra The March of Time. Esta voz se entronca perfectamente con los postulados del documental expositivo (Nichols, 1997). La voz over no posee cuerpo. "Como una forma de locución directa, habla sin mediación a la audiencia, pasando por alto a los «personajes» y estableciendo una complicidad con el espectador: juntos entienden la imagen y así la ubican" (Doane, 1980: 42).

Un segundo aspecto para considerar es la importancia que cobró en esos años el neorrealismo italiano. La utilización de locaciones reales, la salida del estudio, e incluso, en algunos casos, el tono melodramático de las historias puede considerarse

1 Este tipo de narraciones también se relacionan con los police procedurals, que consisten, justamente, en poner en el centro de sus narraciones las pesquisas llevadas adelante por la policía para descubrir crímenes hasta llegar a la captura de los criminales.

2 Creemos necesario señalar que en el film noir se prioriza más la voz en off a cargo de uno de los personajes, a diferencia del semidocumental que trabaja con una voz over, incorpórea. Volveremos sobre este punto más adelante al trabajar sobre el corpus nacional.

3 La traducción es propia. 
influencia de los films italianos. Al respecto, Borde y Chaumeton concluyen que "es por este fácil camino del 'thriller-reportaje', que el neorrealismo ha degenerado en América" (1958: 89). El renombrado crítico uruguayo Homero Alsina Thevenet señala la Segunda Guerra Mundial como uno de los elementos que permiten explicar esta tendencia. La querra "despertó el interés de la cinematografía y del público por la realidad contemporánea, como lo probaría simultáneamente el auge del neorrealismo italiano" (1974: 156). Sin embargo, una diferencia clave en relación con los films italianos es que el principal interés de estos, tal como lo expusiera uno de sus principales ideólogos, Cesare Zavattini, era el retrato de los protagonistas de la vida cotidiana (en Williams, 1980: 30), "los dramas colectivos de su tiempo" (en Agel, 1957: 26).

El estilo de estos films fue adaptado a otras nacionalidades, por lo que nos ocuparemos del arribo del semidocumental a la industria cinematográfica argentina. Para ello, podemos recuperar las palabras de Emilio Bernini sobre el funcionamiento de los géneros en nuestro país:

el cine argentino, aun industrial, durante una década, debió negociar, en términos estéticos y políticos, con la industria de donde proceden los géneros cinematográficos, es decir con Hollywood, para transponerlos a las condiciones de producción de una industria proporcionalmente más modesta y a una cultura heterogénea. De modo que los géneros en el cine argentino ya, de entrada, son una transposición de los géneros hollywoodenses y como toda transposición producen transformaciones textuales, genéricas (2016: 185).

¿Cuáles serían entonces las transformaciones textuales del policial semidocumental en la Argentina? Para poder comprender estas cuestiones y analizar la representación de sus personajes, abordaremos Apenas un delincuente (1949, Hugo Fregonese), el primer semidocumental argentino, y la trilogía policial de Don Napy: Captura recomendada (1950), Camino al crimen (1951) y Mala gente (1952).

Hugo Fregonese encaró la realización de Apenas un delincuente tras su estancia en Estados Unidos bajo contrato con la productora Metro-Goldwyn-Mayer. El programa del film presentaba el siguiente lema: "Por primera vez llega a la pantalla argentina la más moderna de las técnicas del cine -la semidocumental" (Heraldo del cinematografista, 1949: 57). Podría pensarse que el realizador trajo la idea de adaptar las técnicas de los policiales norteamericanos tras su primer paso por Hollywood; sin embargo, no hemos podido hallar ninguna mención en las escasas entrevistas a Fregonese sobre la influencia de estos modelos en su obra, ni la productora del león se caracterizaba por este tipo de films.

En una nota publicitaria en la revista Radiolandia de 1948 en la que se anunciaba el rodaje del film, titulado por entonces Mientras Buenos Aires duerme, el realizador decía:

"El cine norteamericano está entusiasmado con la semidocumental". [...] Explicó entonces que era la influencia de grandes expresiones del cine mundial: Roma, ciudad abierta y Lustrabotas, los dos éxitos más rotundos de la nueva alma italiana. Semidocumental llaman los yanquis a las producciones con argumento que se refieren a cosas auténticas y que se filman igualmente en lugares auténticos (Radiolandia, $\mathrm{n}^{\circ}$ 1036, 12/06/1948).

\footnotetext{
4 En países como España, en los mismos años, se lanzaron Apartado de correos (1950, Julio Salvador), y Brigada criminal (1950, Ignacio lquino), mientras que Akira Kurosawa señalaba la influencia de La ciudad desnuda para su Perro callejero (Nora Inu, 1949).

5 Otros films lanzados con el título de semidocumentales en Argentina que hemos podido rastrear son Mujeres en sombra (1951, Catrano Catrani), Mercado negro (1953) y La delatora (1955), ambos dirigidos por Kurt Land.

6 Más adelante, Fregonese relataría otro motivo de la decisión de salir a filmar en exteriores: “No teníamos galerías
} 
Esto demuestra que el término tenía múltiples interpretaciones y que el film no supone una mera transposición del modelo norteamericano, sino que se resalta la influencia del neorrealismo al igual que la veracidad de los hechos.

En su reseña del film, Domingo Di Núbila señaló que el argumento estaba

basado en dos hechos famosos de los anales porteños: la estafa cometida por un hombre que, sabiendo que su condena no sería superior a seis años, escondió el dinero mal habido para gastarlo cuando recobrara su libertad, y la fuga de presos de la Penitenciaria Nacional a través de un túnel cavado pacientemente (1959: 114).

Los escritos posteriores sobre el film suelen repetir esta afirmación, pero no explicitan cuáles son los "dos hechos famosos" que ofician de inspiración. En la nota ya citada de Radiolandia, Fregonese contó que el proyecto haría referencia a "un hecho que en su hora apasionó a la opinión pública: el personaje central será, posiblemente, Roura, un cajero que huyó hace varios años llevándose casi un millón de pesos, para ser encontrado, al cabo de tres meses en Santa Fe" (Radiolandia, $\left.\mathrm{N}^{\circ} 1036,12 / 06 / 1948\right)$. El segundo hecho, según el periodista Calki, que ofició de continuista en el film, es la fuga de los anarquistas del Penal de Punta Carretas en Uruguay en el año 1931 (Gillo, 1974: 11). Tanto la fuga carcelaria como el caso del cajero de la empresa Continental, Jorge Roura, habían tenido lugar dos décadas antes, por lo que la actualidad y autenticidad, por lo menos en relación con sus contrapartes norteamericanas, pueden discutirse. Más aún, el film abre con un cartel que anuncia: "Esta es una historia de la ciudad. Sucedió, o pudo suceder hace varios años... Entonces las cárceles no eran como ahora... Y por un resquicio del código se filtró la idea de un delito audaz".

Tras la positiva recepción de Apenas un delincuente se produjo un conjunto más de policiales semidocumentales, de los cuales los más importantes son los tres dirigidos por Don Napy coescritos con Antonio Corma. Si bien comparten algunos elementos con el film de Fregonese, y probablemente sean los ejemplos que mejor se acomodan a la definición del semidocumental practicado en Estados Unidos, poseen múltiples particularidades que permiten distinguirlos, incluso entre sí. Una vez más, se utilizaron locaciones reales y las publicidades hacían hincapié en la veracidad de los episodios narrados. En el primero de los films, el periodista especializado en policiales Luis A. Zino ofició de recopilador de casos (y hay un cameo de él interpretándose a sí mismo), pero una vez más no se explicita de dónde proceden los casos. Estos films contienen múltiples momentos que rompen con la cuarta pared y refuerzan la noción de verismo, pero poseen un tono burlón. Un aspecto para destacar es la relación que establecen con la radio: gran parte del elenco y el realizador provenían del medio. Cabe indagar ahora los films en particular y ver qué representaciones ofrecen en sus personajes masculinos a partir de la división entre los policías, hombres que no presentan una escisión

disponibles hasta diciembre y no había cámaras tampoco, estaban todas ocupadas. Había que esperar hasta diciembre. Yo no quería esperar, sino seguir, ya tenía el libro listo y deseaba empezar. Conseguimos una cámara de Alex para filmar títulos, sin sonido. Así la filmamos, sin sonido" (Russo, 2013: 193).

7 El realizador presenta un distinto origen de la trama en una entrevista realizada en 1966 (cf. Nota 10).

8 A pesar de lo expuesto, en otras fuentes los participantes citan distintos orígenes para la inspiración del film. Según uno de sus actores, “la fuga se recreó en el mismo lugar en que se había llevado a cabo -comentó Nathan Pinzónen los sucesos reales. Se filmó en el túnel que habían construido los evadidos y también en la propia carbonería desde donde finalmente escaparon" "“Apenas un recuerdo (pero muy hermoso)", Crónica, 16/05/1985, disponible en Museo del Cine). Pinzón hace referencia a la fuga de la Penitenciaría Nacional en 1923, retratada en el film La fuga (2001, Eduardo Mignogna), que se condice con la reseña de Di Núbila. Ambos eventos poseen múltiples similitudes e incluyen el escape de presos anarquistas. Por otro lado, Fregonese en una entrevista declaró que la trama se basó en "una idea mía sobre un asunto que realmente había sucedido. Se me ocurrió esa idea porque el hermano de este delincuente estudiaba conmigo en la Universidad y yo conocía el asunto bastante bien" (Martialay et al., 1966: 211). 9 Este tipo de leyendas era común en el período y se relaciona con la censura oficial, pero su presencia aquí parece contradecir la esencia del estilo semidocumental. 
entre vida profesional y privada, cuyo trabajo es servir a la sociedad oficiando como guías morales y padres, y los delincuentes, de doble vida, algo necesario para llevar adelante sus crímenes.

\section{La Ley y el orden: los personajes masculinos del semidocumental argentino}

Uno de los aspectos más analizados del film noir es la llamada crisis de la masculinidad (Chopra-Gant, 2006; Krutnick, 1991). Los protagonistas masculinos expresan una desestabilización sexual y psicológica, que suele relacionarse con los temores de la época encarnados principalmente en la relación con el sexo opuesto y la femme fatale. Los films semidocumentales, por el contrario, exponen la norma masculina a partir de las fuerzas de la ley y sus oficiales, mientras que los delincuentes encarnan pequeños deslices de un sistema social que funciona correctamente. Estas características aplican también al caso argentino, tal como sugiere Elena Goity: "el cine policial argentino, si bien sigue patrones externos, les proporciona elementos propios, con afán de 'verosimilizarlos', haciendo reconocibles a sus personajes y sus ambientes” (2000: 403).

En Apenas un delincuente las fuerzas de la ley no tienen tanta presencia en pantalla, pero sí gran relevancia en el relato, ya que uno de los policías clausura la narración para reforzar la moraleja. Apenas un delincuente deja completamente de lado el aspecto procedural del estilo semidocumental, para marcar una importante diferencia con los exponentes norteamericanos: el protagonismo del delincuente.

El film se divide en dos grandes secciones, correspondientes a los hechos reales que sirvieron de inspiración: en la primera se narra la estafa del contador José Morán a la empresa en la que trabaja por medio millón de pesos, tras enterarse de que la pena máxima de prisión son seis años sin importar el monto sustraído; en la segunda, su encarcelamiento y fuga con un grupo de presos anarquistas que lo engañan para robarle su dinero. La estructura del film no es lineal, sino que las primeras imágenes son de una persecución automovilística que concluye con uno de los coches volcando en la carretera, escena que se retomará sobre el final de la narración. La imagen del coche en llamas y la policía acercándose se convierte en la primera plana de un periódico que anuncia "Capturan herido a José Morán". De esta manera se pasa a la redacción del diario, donde se le encarga a un periodista que escriba una nota sobre el caso haciendo foco en la familia del delincuente. El motivo de la nota periodística refuerza el carácter verídico del relato, pero no se vuelve sobre ello hasta el final del film y nunca se ve el rostro del periodista.

La secuencia en la que finalmente se presenta al protagonista es una de las más icónicas del film: retrata el agitado mundo de la ciudad de Buenos Aires. Con posiciones de cámara poco habituales, las primeras imágenes nos muestran a personas anónimas mientras la ciudad empieza a vivir y los transportes públicos las llevan a diferentes destinos: tomas aéreas desde helicóptero o al ras del piso o desde las paredes de los vehículos, etc. En este punto ingresa el relato over:

10 A pesar de esto, autores como Jorge Ruffinelli han escrito que Fregonese "reiteró con talento [...] una modalidad del policial entonces en boga en el cine norteamericano (gracias a La ciudad desnuda [Naked City, 1948], de Joles (sic) Dassin, entre otros títulos. Se trataba de dar cuenta de historias verídicas, urbanas, con un estilo directo, de escenas y diálogos cortos y efectivos, correlatos de la "novela dura" sobre hampones, delitos y cárceles" (2011: 45).

11 Motivo que sugiere que el cartel con el que inicia fue puesto de forma compulsiva. Por otro lado, este motivo narrativo se relaciona con el de El ciudadano, que narra una investigación periodística sin mostrar el rostro del periodista. 
Esta es la ciudad de los nervios excitados que todos los días atrae a su centro millares de seres impacientes. Los agita, los devora, se empujan, se atropellan en una prisa sin sentido, siempre en apuro, en apuro. ¿Por qué? ¿Para qué? ¿Adónde quieren llegar? ¿Adónde van? Casi todos trabajan, sueñan, estudian. Trabajan estimulados por el ritmo agitado de la ciudad, pero algunos quedan prisioneros de esa mala fiebre, de esa impaciencia por llegar demasiado rápido, de tenerlo todo, aunque sea saltando la valla.

Finalmente aparece el protagonista.

Veamos a uno de ellos: es José Morán, tiene veintiocho años y es el más impaciente de todos. Por su cuidada elegancia no parece un modesto empleado de doscientos cincuenta pesos mensuales. Entremos en su vida. Para nuestro personaje el dinero es todo, la llave maestra que le abrirá la puerta de todos sus sueños, aunque deba usarla como ganzúa, y el juego es una esperanza de liberación, la escalera mágica que lo hará llegar antes... y así ocho años de rutina. Él no es más que una minúscula pieza de un gran engranaje, encasillado entre las ocho y las doce, entre las dos y las seis. Hoy, ayer, mañana, siempre igual, subiendo y bajando, y siempre a ras de la tierra.

Mientras la voz over continúa su relato, la imagen se congela sobre Morán (Jorge Salcedo), un procedimiento también atípico de la época que sirve para subrayar, al igual que el texto del relato, que se trata de un ciudadano más entre la muchedumbre. A lo largo de la primera mitad del film, el personaje se exhibe rodeado de multitudes aprovechando la filmación en exteriores: sumada a la imagen de presentación en las calles, se lo muestra viajando en colectivo observando coches lujosos ansiando tener uno, subiendo en ascensor rodeado de gente a la que mira con desprecio, en el Hipódromo perdiendo una apuesta y, finalmente, en el Casino de Mar del Plata. En este sentido, Morán es un ciudadano típico pero también excepcional: estamos ante el retrato del hombre porteño por excelencia. Si uno de los principales personajes del film es la ciudad, como deja en claro la escena descripta, tiene sentido que se retrate a un habitante tipo también. El material de publicidad lo deja en claro:

Había que encontrar el tipo porteño para el personaje porteño [...] que tiene una cierta manera de hablar, como a empujones, una altanería cercana a la del orillero "compadrito" fin de siglo; una vanidad exagerada que mezcla un cierto insatisfecho complejo de evasión de sí mismo; una siempre alerta y a un tiempo ingenua expectativa para que nadie lo "madrugue" $y$, en el fondo, bien en el fondo, un lindo sentido de la hombría y de la dignidad (EXTRA).

Estamos entonces ante un antihéroe que posee las aspiraciones de ascenso social comunes al ciudadano medio de la época. El personaje tiene un trabajo estable, una familia que lo quiere y una novia. Sin embargo, sus ambiciones son mayores. En este sentido, la película plantea una relación por momentos ambivalente con el protagonista masculino, que genera identificación, preocupación y rechazo a la vez por su conducta moral. El rol del hermano, encarnado por Tito Alonso, juega un papel clave para ello. Este personaje encarna las vías legales de ascenso social que el protagonista no planea llevar a cabo (su opuesto), tal como queda de manifiesto en la escena del desayuno familiar con la madre. Ahí, el hermano le espeta que él trabaja, estudia y la poca plata que le sobra la deja en la casa familiar, mientras que José no aporta nada y se gasta su plata en ropa. La escena concluye con el hermano cantando un fragmento del tango Niño bien: "Niño bien, pretencioso y engrupido. Que tenés berretín de figurar".

En esta primera sección aparecen los personajes femeninos del film y se percibe el tono melodramático del relato familiar: además de la madre, se encuentran su 
novia y una mujer a la que conquista durante su noche de juego en el casino. El personaje de la novia es interesante, especialmente para este período del cine nacional: si bien lo espera a Morán fielmente, estudia abogacía y ella le da el dato de que la pena es la misma por defraudación, sin importar la cantidad de dinero. Esto lo decide a realizar la estafa. La madre, por otro lado, cumple el rol más típico de madre abnegada y sufrida.

La ambivalencia en la construcción del personaje se hace patente durante la escena de la estafa, en la que se genera suspenso para ver si será descubierto o no. Pero es todavía más nítida en el momento de la captura. Morán llega al andén de la estación del tren escoltado por policías y encuentra a una multitud vitoreándolo. Los mira riéndose desde la ventanilla y exclama: “¿Lo ve? Me envidian. Quisieran hacer lo que yo hice. Pero les falta valor. ¡Giles!". Esta escena permite resumir toda la primera sección y apreciar la ambigüedad del film con su protagonista.

La segunda mitad de la película transcurre en el penal y comienza con el ingreso del protagonista. Estas secuencias son una ilustración del proceso de encarcelamiento. Se le quita su identidad a Morán, se le otorga un número y se le da un trabajo. Si bien el propósito de la cárcel es reinsertar a los delincuentes en la sociedad, más importante es configurar a Morán como un exponente que contraría la moral del trabajo y debe pensarse en parámetros propagandísticos: Morán encontrará su perdición en la cárcel. En contraste con el protagonista, en este espacio aparece un segundo tipo de criminal, violento y peligroso para la sociedad: el anarquista. La banda de anarquistas planea una fuga y se propone quitarle el dinero escondido al protagonista haciéndole creer que su hermano se está quedando con el botín. En este sentido, resulta útil la distinción entre delito privado y delito político. En el delito privado, se trata de "una excepción a la regla (eximirse de ella en ocasiones); [...] no hace más que desviarse de la ley (aunque deliberadamente); puede a la vez detestar su propia transgresión y desear sólo eludir la ley, sin negarle formalmente obediencia", mientras que el delito político "rechaza la autoridad de la ley misma, [...] convierte en regla de su acción obrar contra la ley; por tanto, su máxima no sólo se opone a la ley por defecto, sino incluso dañándola o, como se dice, diametralmente, como contradicción (digamos, de un modo hostil)" (Kant, 2005: 153).

El film no se interesa por los motivos políticos de la banda, sino que remarca la actitud errónea del protagonista. Uno de estos convictos le dice: "Tu ambición tiene los pies muy rápidos [...] Tenés la enfermedad de la ciudad. Querés llegar demasiado rápido a ninguna parte", diálogo que se asemeja al del relator extradiegético. El gran error de Morán será justamente su desconfianza en la gente, especialmente en la familia, y su ambición, que lo llevará finalmente a la muerte.

Dos de los semidocumentales de Don Napy, Captura recomendada y Mala gente, son films episódicos que cuentan tres historias sobre distintos delitos: estafas, tráfico de drogas, robos y una historia de crímenes pasionales. ${ }^{13}$ Como no podría ser de otra forma, se trata de films que asumen la posición oficial, ${ }^{14}$ pero una vez más los agentes de la ley no pueden calificarse como protagonistas. Captura recomendada y Camino al

12 Este personaje en realidad no es más que un cameo de la esposa de Fregonese, la actriz estadounidense Faith Domergue.

13 La publicidad de Captura recomendada era la siguiente: “La peca, el tráfico de alcaloides, el asalto y la historia verídica de los pistoleros, reunidos en una extraordinaria superproducción semidocumental, basada en hechos reales que conmovieron a la opinión pública y extraídos de los archivos de la Policía Federal”. Citado en Heraldo del cinematografista, vol, XIX, Año 20, 02/08/1950, núm. 987, 209.

14 Estos films contaron con diversos apoyos oficiales como se puede constatar en los agradecimientos a la Prefectura Nacional Marítima y la Gendarmería Nacional, la participación como asesores de comisarios, la dedicatoria al "personal a sus órdenes que intervino en los hechos que se muestran" y el escudo de la Nación en los créditos de Captura recomendada. 
crimen presentan un enfoque procedural con escenas que muestran cómo el Inspector Campos (Eduardo Rudy) ${ }^{15}$ descubre a los responsables de los delitos haciendo gala de la última tecnología disponible de la Policía Federal. Sin embargo, la mayor parte del relato se dedica a mostrar los planes de los diversos criminales.

Uno de los episodios de Captura recomendada exhibe cómo la policía rastrea a los criminales a partir del análisis de una de las balas recuperadas de la escena del crimen. "Las estrías que dejan todas las armas en el plomo de las balas fue fotografiada en su desarrollo circular con el Aparato Fotocomparador Sistema Argentino Belaunde". En Camino al crimen la pista es el rouge de un pintalabios en un libro, el cual se compara con la marca en una taza de café: "Para eso recurrimos al Espectógrafo, extraordinario aparato que sirve para analizar la luz en general, y la que emiten los cuerpos en su combustión. Se establece entonces con precisión si están constituidos por las mismas materias". Estas secuencias, similares a las de los ejemplos norteamericanos, se asemejan estéticamente a los noticieros de la época, pero se encuentran narradas por la voz en off de Campos. Esto marca una diferencia con la voz over incorpórea, pero es necesario señalar que Rudy era el relator del noticiero Sucesos argentinos y que por lo tanto se identificaba con "la voz del gobierno, que aseveraba y aconsejaba" (Kriger 2007: 13).

El personaje de Campos en estos dos films nos permite abordar la concepción ideal del hombre de la ley del período. En Captura recomendada el Inspector narra las tres historias a un periodista en el contexto de una ceremonia de homenaje a oficiales, con el objetivo de "contarle al público la vida y el trabajo de ustedes (la policía)". Cada una de ellas se relaciona con su vida privada y amorosa: la primera investigación lo obliga a aplazar su compromiso, el segundo caso interrumpe sus planes de luna de miel y el tercero lo requiere cuando tiene a su hijo recién nacido en brazos. En la novelización de la revista Radiofilm se retrata este aspecto de la historia con las siguientes palabras:

También los hombres de la policía tienen su corazoncito; y he aquí que Campos, empleado de la Dirección de Investigaciones, ha fijado para hoy la fecha de su compromiso con Susana, su novia. Tiene ya los anillos, habla con ella anunciándole la hora de su llegada a la casa, cuando un llamado telefónico desbarata todos sus planes. [...] Quedan la novia y los invitados a la fiesta esperando, mientras Campos, cumpliendo con su deber, procede a la detención (“Captura Recomendada. Versión periodística de un argumento cinematográfico", Radiofilm, 15/02/1950, núm. 240: 17).

Como deja en claro este texto, la vida profesional y la privada de los oficiales se encuentran entrelazadas y ellos están dispuestos a sacrificar aspectos de la segunda por el bienestar de la sociedad. El film concluye con la ceremonia mientras Campos habla a cámara, haciendo referencia a su esposa e hijo que lo acompañan: "Nosotros lo hacemos [arriesgar la vida] por ella, por él, por usted. Por los niños inocentes, por las mujeres de nuestros hogares, por los seres indefensos y por la seguridad de todos los habitantes de la Patria". El rostro de Rudy hablando directamente a cámara es sobreimpreso sobre imágenes de gente en las calles, chicos en escuelas y el plano final del Obelisco. Los agentes de la policía constituyen el Estado y encarnan figuras paternales que protegen a los ciudadanos como miembros de una gran familia, con mano dura pero tierna a la vez. Este aspecto también queda patente en Camino al crimen, en el que se adopta como marco narrativo el rodaje de un film ficticio sobre un

15 Se ha indicado que "el personaje de Campos provenía del programa de radio Ronda policial, interpretado por Eduardo Rudy" (Giacomelli, 2020). Pero este dato no aparece resaltado en la cobertura de su estreno y el programa radiofónico era de la década anterior. 
caso en el que también intervino Campos. ${ }^{16}$ El Inspector llega a la galería de filmación el día inicial con su hijo, quien saluda al realizador del film de ficción (y su padre lo obliga a decirle "señor").

Dado que la película anterior concluye con la presencia del hijo y esta comienza con una enseñanza de disciplina, se prepara al espectador para el rol que jugará Campos en esta nueva historia, oficiando de guía moral para diversos personajes. En el set de filmación adelanta la moral de la historia:

Está por llegar uno de los protagonistas de esto que van a filmar. Les va a gustar. Es un muchacho simpático, inteligente, pero que un día equivocó el camino por culpa de unos compañeros, malos compañeros, muchachos influenciados por malas novelas, por películas en que el pistolero se convierte en héroe. Las andanzas de todos ellos, lo que ustedes van a llevar al cine sé que es un poco amargo. No importa: servirá de enseñanza, también son amargas las medicinas... pero curan.

Camino al crimen narra los delitos de una banda de ladrones liderada por Tito Alonso. Estos engañan a Luis (Juan Carlos Altavista), el "muchacho simpático" del relato, para hacerlo cómplice de sus delitos. Campos descubre, de forma un tanto intuitiva, que el personaje de Luis no está interesado en tal vida y le dice que la policía lo "sabe todo y lo que no, lo averigua". A lo largo del relato, le da consejos paternales para rescatarlo de la situación en la que se encuentra. Tras la detención de los criminales, el film regresa al estudio de filmación, al que llega Luis con su flamante esposa: "un muchacho que comprendió que hay un solo camino que conduce a la verdadera dicha: el de la honestidad. [...] Que su conducta sirva de ejemplo". Una vez más, la policía oficia como consejera, además de asegurar el orden y la captura de los elementos criminales, combinando la fuerza con un espíritu comprensivo.

La banda delictiva, por otro lado, posee rasgos similares a los de José Morán: uno trabaja en la misma oficina que Luis, pero protesta cuando su jefe le sugiere la posibilidad de un ascenso ya que no tienen interés en una vida dentro de la ley. A diferencia del delincuente solitario, las bandas de delincuentes, como propone Bourdieu, "encuentran su principio, paradójicamente, en el miedo a perder la estima o la admiración del grupo, de «perder la cara» delante de los «colegas», y de verse relegado a la categoría típicamente femenina de los «débiles», los «alfeñiques», las «mujercitas», los «mariquitas», etc." (2000: 70). Así deben leerse las múltiples escenas de peleas de puños entre el personaje de Alonso y sus distintos secuaces, en claro contraste con el funcionamiento de los agentes de la ley: "Aquí trabajamos todos para un mismo fin. En la policía no hay más que un yo: la policía".

El último film de la trilogía, Mala gente, a veces es inscripto dentro de esta serie, pero también puede discutirse su pertenencia. Como señala Román Setton "se acerca mucho más al film noir y prescinde casi por completo de la policía y de la indagación" (2016: 94). Sin embargo, la película también contó con el apoyo de la policía y los casos narrados fueron "arrancados de los archivos policiales" (programa del film, en Heraldo del cinematografista, 1952: 23). Sumado a esto, la cobertura de la película durante su estreno subrayaba que los relatos fueron "construidos de acuerdo con hechos registrados en los anales de la delincuencia [...] estos films [los episodios] responden a un propósito documental" ("Mala gente, con tema documental", La Nación, 20/03/1952).

16 Los créditos de la película lo presentan como "El famoso Inspector Campos". Esto puede hacer referencia tanto al film como al hecho de la procedencia radial.

17 La crítica del diario La Razón directamente comienza con la siguiente denominación: "El film documental Mala gente" (“Mala gente”, La razón, 20/03/1952, disponible en el Museo del Cine). 
El primer aspecto que llama la atención en Mala gente es que no solo la policía se encuentra ausente casi por completo, sino que además Eduardo Rudy (el Inspector Campos) interpreta el papel de un ladrón en el primer episodio y en vez de ilustrar el accionar de la policía se muestra el modus operandi del ladrón. Mediante el relato en off, el personaje cuenta cómo selecciona las casas que roba, dónde la gente suele esconder sus bienes preciados, etc. Al igual que los estafadores y traficantes de drogas de Captura recomendada, este personaje lleva una doble vida que le permite operar sin sospechas: "La base de mi éxito fue que siempre me creyeron un hombre decente. Para lograrlo, tomé todas las precauciones: vestía bien, usaba buenas alhajas y trabajaba siempre solo. Nadie, absolutamente nadie conocía mis actividades". Los criminales de Napy no pueden llevar adelante su vida delictiva sin una fachada de ciudadanos respetables, motivo por el que resultan indispensables los perspicaces oficiales de la ley que sacrifican sus vidas personales por el bien de todos. A su vez, el motivo más común es la ambición, tanto en este episodio como en el que se estafa al personaje interpretado por Tato Bores con la compra de un tranvía.

Un párrafo aparte merece el último episodio que deja de lado la ciudad para narrar el crimen pasional de un hombre de campo. Aquí los procedimientos textuales del semidocumental desaparecen por completo y se vuelca hacia una historia melodramática en la que la policía no tiene casi participación. En este sentido, marca el derrotero de las últimas producciones del estilo (Mercado negro) y confirma que "las obras cinematográficas de género policial tuvieron que ser transpuestas a un contexto de producción en el cual el melodrama era la materia prima a través de la que se moldeaban los contenidos" (Giacomelli, 2018: 56).

\section{A modo de conclusión}

El objetivo de este artículo fue doble: por un lado, abordar las transformaciones de un género adaptado a la industria cinematográfica nacional y, por otro, examinar la construcción de los personajes masculinos a partir de las dicotomías ley/crimen y vida privada/pública. El ciclo de policiales semidocumentales argentinos tuvo un período de productividad breve de seis años (1949-1955). Si bien se puede constatar la existencia de distintas apropiaciones, llevadas a cabo por distintas productoras y realizadores, ${ }^{18}$ las similitudes permiten agrupar a los films bajo la misma denominación. En este sentido, pudimos mostrar que los cambios en la adopción del estilo semidocumental fueron múltiples y, en ningún caso, se omitieron las características propias de la cultura argentina, con especial atención a las peculiaridades de la ciudad de Buenos Aires y sus habitantes. También pueden indicarse al respecto las particularidades del starsystem local, según el cual un mismo actor podía pasar de interpretar a un Inspector de la policial a un criminal de guante blanco (Eduardo Rudy) o pasar de ser un ciudadano ejemplar a líder de una banda criminal (Tito Alonso). Otra importante diferencia es el protagonismo de los delincuentes, una característica ausente en los exponentes estadounidenses, que ponen el foco de forma casi exclusiva en las investigaciones de los agentes de la ley. Tanto en Apenas un delincuente como en el primer film de la trilogía de Napy se recurre a la presencia de periodistas (ficcionales y verdaderos) como una estrategia de autenticidad de las historias presentadas.

La masculinidad en los semidocumentales argentinos se ve moldeada por la poética melodrámatica y su concepción maniquea de los personajes, dividida entre oficiales

18 En el caso de Fregonese, estrenó el melodrama De hombre a hombre el mismo año que Apenas un delincuente, y partió hacia Hollywood, donde realizó films en múltiples géneros, entre ellos policiales, ninguno dentro del estilo semidocumental. Por su parte, Napy lanzó la comedia El pecado más lindo del mundo en 1953, su último largometraje de ficción, y el documental en 3D Buenos Aires en relieve (1954). Se trata, como las películas trabajadas aquí, de un film de propaganda que exhibe a Buenos Aires como "la Capital de una gran Nación". 
de la policía conocedores de la naturaleza humana que ofician de padres de los ciudadanos y delincuentes caracterizados por la ambición y el egoísmo. Como señalara Tassara, "el policial argentino, salvo unas pocas excepciones [...] es un claro defensor de la legalidad institucional" (1993: 155). Por este motivo, suelen ser los oficiales de la policía los encargados de los relatos, señalando las moralejas de cada historia, a pesar de que sean los criminales los que pasan mayor tiempo en pantalla y posean más atractivos para los espectadores.

A pesar de tratarse de películas que se plantean a partir de un abordaje realista, los personajes en estas películas encarnan arquetipos. Morán en Apenas un delincuente representa al hombre porteño, un personaje altanero, que mira con desprecio al resto de la gente, incluida su familia. Por otro lado, el Inspector Campos se erige como emblema del semidocumental, encarnando la ley, asumiendo una función paternal con los ciudadanos, castigando a los que infringen las leyes y ofreciendo su consejo y guía a los que solo cometieron un pequeño error. Este oficial de policía simboliza el ideal masculino de la época, severo y tierno a la vez, a la vez que se emparenta a las fuerzas del orden con la figura paterna. Frente a esto, los hombres que cometen crímenes encuentran como única motivación la ambición y llevan adelante una doble vida, oculta para sus conocidos; esta concepción de la criminalidad se asemeja a la del film de Fregonese. En este sentido, los exponentes argentinos cumplen con la máxima señalada por Borde y Chaumeton: "película moralizadora, el [semi]documental norteamericano, es en realidad un documento a la gloria de la policía" (1958: 15). 


\section{Q Bibliografía}

» Agel, H. (1957). Vittorio De Sica. Buenos Aires: Losange.

»Alsina Thevenet, H. (1974). “Informe sobre cine policial”. En: Feldman, S.; Mahieu, A. y Alsina Thevenet, H., Violencia y erotismo. Constantes en el cine de todas las épocas. Buenos Aires: Editorial Cuarto Mundo, 150-197.

»Bernini, E. (2016). “Políticas del policial en el cine argentino”. En: Setton, R. y Pignatiello, G. (comps.): Crimen y pesquisa. El género policial en la Argentina (1870-2015): literatura, cine, televisión, historieta y testimonio. Buenos Aires: Título, 185-192.

»Borde, R. y Chaumeton E. (1958). Panorama del cine negro. Buenos Aires: Losange.

» Bourdieu, P. (2000). La dominación masculina. Barcelona: Anagrama.

»Canham, K. (1973). The Hollywood Professionals Volume 1. New York: Tantivy Press.

»Chopra-Gant, M. (2006). Hollywood Genres and Postwar America: Masculinity, Family and Nation in Popular Movies and Film Noir. Londres: I.B. Tauris.

»Connell, R.W. (2003). Masculinidades. D.F. : UNAM.

"Coursodon, J.P. (1996). “La evolución de los géneros”. En: Historia general del cine Volumen VIII. Estados Unidos (1932-1955). Madrid: Cátedra, 207-309.

"Crónica, “Apenas un recuerdo (pero muy hermoso)", 16/05/1985, s/p.

»Di Núbila, D. (1959). Historia del cine argentino II. Buenos Aires: Cruz de Malta.

» Doane, M.A. (1980). "The Voice in the Cinema: The Articulation of Body and Space". Cinema/Sound, $\mathrm{n}^{\circ}$ 60, 33-50.

» EXTRA. Material publicitario de Apenas un delincuente. Disponible en: https:// issuu.com/museodelcineba/docs/extra.

» Giacomelli, D. A. (2018). “La representación del criminal en el film noir argentino desde 1942 hasta 1956”. En: Kriger, Clara (comp.), Imágenes y públicos del cine clásico argentino. Tandil: Universidad Nacional del Centro de la Provincia de Buenos Aires, 55-74.

» Giacomelli, D. A. (2020). "Periodistas, criminales y pantallas. El cine policial negro argentino y su relación con la prensa durante el peronismo”. Sociohistorica: Cuadernos del CISH, no. 46. En: https://www.sociohistorica.fahce.unlp.edu.ar/ article/view/SHe109; obtenido el 10/01/2021.

» Gillo, María Esther. "Buenos Aires, la ciudad desnuda”. La opinión cultural, 21/04/1974: 11.

» Goity, E. (200o). “Cine policial. Claroscuro y política”. En: España, Claudio (comp.), Cine argentino. Industria y clasicismo I y II. 1933-1956. Buenos Aires: Fondo Nacional de las Artes, 400-473.

" Heraldo del cinematografista, Vol, XIX, - Año 20. 02/08/1950, No. 987, 209.

" Heraldo del cinematografista, Vol. XIX - Año 18. 30/03/1949, No. 917, 57.

»Heraldo del cinematografista, Vol. XXII, Año 21, 26/03/1952, No. 1078. 
»Kant, Immanuel (2005). La metafísica de las costumbres. Traducción: Adela Cortina Orts y Jesús Conill Sancho. Tecnos: Madrid.

» Kriger, C. (2007). “El noticiero Sucesos Argentinos”. Historiapolítica.com. Sitio web de Historia Política: http://historiapolitica.com/datos/biblioteca/kriger. pdf; obtenido el 01/08/2020.

» Kriger, C. (2009). Cine y peronismo. Buenos Aires: Siglo XXI.

» Krutnik, F. (1991). In a Lonely Street. Film noir, genre, masculinity. New York: Routledge.

»La Nación, “Mala gente, con tema documental”. 20/03/1952.

» La razón, “Mala gente”. 20/03/1952.

» Martialay, F.; Pala, J.M.; Torres A.M. (1966). “Entrevista con Hugo Fregonese”. Film Ideal, $\mathrm{n}^{\circ} 188,210-213$.

"Nichols, B. (1997). La representación de la realidad. Cuestiones y conceptos sobre el documental. Madrid: Paidós.

" Radiofilm, "Captura Recomendada. Versión periodística de un argumento cinematográfico", 15/02/1950, Número 240, 17-19.

»Radiolandia, "Una 'semidocumental' sobre Buenos Aires nocturno rodará pronto Hugo Fregonese", n 1036, 12/06/1948, s/p.

»Ruffinelli, J. (2011). América Latina en 130 películas. Santiago de Chile: Uqbar.

»Russo, G. (2013). "Conversación con el director Hugo Fregonese. 17 de mayo de 1979”. En: Russo, G; Insaurralde, A., Más allá del olvido. Conversaciones inéditas con grandes del cine nacional. Buenos Aires: Prosa y Poesía Amerian Editores.

»Setton, R. (2016). “Los engaños delictivos y la indagación de la verdad en las películas policiales de Don Napy: la pesquisa como trabajo colectivo en el cine policial del peronismo". Romanische Studien, Beihefte 2, Cine de investigación, 93-106.

" Tassara, M. (1993). “El policial. La escritura y los estilos”. En: Wolf, S. (compilador), Cine argentino. La otra historia. Buenos Aires: Ediciones Letra Buena, 147-167.

»Williams, C. (ed.) (1980). Realism and the cinema. A reader. Londres: British Film Institute. 